\title{
STRATEGI UNIT USAHA SYARIAH BANK UMUM KONVENSIONAL DALAM MENGHADAPI SPIN OFF 2023 (STUDI PADA PT. BPD RIAU DAN KEPULAUAN RIAU)
}

\author{
Yessi Nesneri ${ }^{1}$, Fitri Hidayati ${ }^{2}$ \& Ulfiah Novita $^{3}$ \\ ${ }^{1,2 \& 3}$ Fakultas Ekonomi dan Ilmu Sosial, Universitas Islam Negeri Suska Riau \\ Email :yessi.nesneri@uin-suska.ac.id, fitri.hidayati@uin-suska.ac.id, \\ ulfiah.novita@uin-suska.ac.id
}

\begin{abstract}
ABSTRAK
Pemisahan (spin off) Unit Usaha Syariah (UUS) milik Bank Umum Konvensional merupakan salah satu usaha yang dilakukan pemerintah untuk mempercepat pertumbuhan pangsa pasar Perbankan Syariah di Indonesia seiring dengan usaha pemenuhan hak bagi mayoritas muslim di Indonesia yang menginginkan adanya fasilitas keuangan yang sesuai dengan kepercayaannya. Penelitian ini bertujuan untuk mengetahui strategi Unit Usaha Syariah PT. BPD Riau dan Kepulauan Riau dalam menghadapi kewajiban pelaksanaan spin off maksimal tahun 2023. Penelitian ini bersifat gagasan deskriptif yang dilakukan dengan kegiatan investigasi teoritis (literature review). Hasil penelitian menunjukkan bahwa Unit Usaha Syariah PT. BPD Riau dan Kepulauan Riau Sebelumnya sudah melakukan Proses spin off yang dimulai dari tahapan persiapan spin off, aspek bisnis, aspek keuangan, aspek organisasi dan Sumber Daya Insani (SDI), Aspek teknologi dan informasi, serta aspek legal dan perizinan. Akan tetapi berdasarkan hasil Rapat Umum Pemegang Saham (RUPS) pada tanggal 22 April 2019 di ketahui bahwa Unit Usaha Syariah PT. BPD Riau dan Kepulauan Riau tidak bisa terpisahkan secara prinsip dengan Bank Induknya, karena PT. BPD Riau dan Kepulauan Riau memilih untuk melakukan konversi menjadi Bank Umum Syariah.
\end{abstract}

Kata Kunci : Spin off, Unit Usaha Syariah, Bank Syariah.

\begin{abstract}
The spin-off of Sharia Business Unit (UUS) belonging to Conventional Commercial Banks is one of the efforts made by the government to accelerate the growth of the Islamic banking market share in Indonesia, which is in line with efforts to fulfill the rights of the majority of Muslims in Indonesia who want financial facilities in accordance with their beliefs. This study aimed at determining the strategy of the Sharia Business Units of PT. BPD Riau and Riau Island in facing the obligation to implement maximum Spin Off in 2023. This research was a descriptive idea carried out by theoretical investigative activities (literature review). The research findings showed that the Sharia Business Units of PT. BPD Riau and Riau Island had previously carried out a spin off process starting from the spin-off preparation, business aspects, financial aspects, organizational and SDI aspects, technology and information aspects, as well as legal and licensing aspects. However, based on the results of the General Meeting of Shareholders (GMS) on April 22, 2019, it was found that the Sharia Business Units of PT. BPD Riau and Riau Islands could not in principle be separated from their parent banks because PT. BPD Riau and Riau Islands had chosen to convert to Islamic Commercial Banks.
\end{abstract}

Keywords : Spin Off, Sharia Business Units, Islamic Bank. 


\section{PENDAHULUAN}

Perbankan merupakan salah satu lembaga keuangan yang dapat mempengaruhi pertumbuhan ekonomi suatu negara (Indra dan Edwin, 2017). Sebab, perbankan berfungsi sebagai lembaga yang melaksanakan intermediasi. Sehingga ketika terjadi penurunan fungsinya, secara tidak langsung akan terjadi perlambatan pertumbuhan ekonomi di negara. Oleh sebab itu untuk pergerakan roda perekonomian yang lebih cepat, terlebih dahulu pemerintah harus membenahi sektor perbankan.

Salah satu upaya yang dilakukan oleh pemerintah untuk membenahi sektor perbankan yakni dengan melakukan penyempurnaan UU No. 7 tahun 1992 menjadi UU No. 10 Tahun 1998 tentang perbankan, yang secara tegas menjelaskan bahwa terdapat dua sistem dalam perbankan (dual banking system) yaitu sistem perbankan konvensional dan sistem perbankan syari'ah. Namun kebijakan pemerintah tentang pemberian izin pendirian unit usaha syariah oleh bank umum konvensional hanya bersifat sementara dan wajib spin off 2023 untuk dapat mendorong pengembangan perbankan syariah (Rongiyati, 2015).

Kehadiran Perbankan Syariah di tengah-tengah perbankan konvensional dilatarbelakangi oleh keinginan masyarakat Islam untuk menghindari riba dalam kegiatan muamalahnya. Hal ini didukung temuan survey BI yang mendapatkan 30 persen dari umat Islam yang tidak mau berhubungan dengan bunga bank (riba). Sebab, Perkembangan sektor perbankan tidak terlepas dari peran para nasabah yang memberikan kepercayaan terhadap pihak perbankan untuk penyimpanan asset keuangannya. Sehingga keinginan nasabah merupakan prioritas utama yang harus dipenuhi.

Selain itu, untuk mengembangkan industri perbankan syariah di Indonesia,
Bank Indonesia secara tegas menjelaskan bahwa Bank Umum Konvensional yang memiliki Unit Usaha Syariah wajib menjadi Bank Umum Syariah paling lambat 15 tahun sejak berlakunya Undang-undang Nomor 21 tahun 2008 tentang perbankan syariah. Hal ini mengindikasikan bahwa Setiap Bank Umum Konvensional harus memisahkan diri dari Unit Usaha Syariah yang dimilikinya paling lambat pada tahun 2023. Namun, pemisahan (spin off) Unit Usaha Syariah bisa saja dilakukan sebelum tahun 2023 apabila nilai aset Unit Usaha Syariah telah mencapai $50 \%$ dari total nilai aset Bank Umum Konvensional induknya.

Pemisahan (spin off) Unit Usaha Syariah yang dimiliki oleh Bank Umum Konvensional merupakan salah satu usaha yang dilakukan pemerintah untuk mempercepat pertumbuhan pangsa pasar Perbankan Syariah di Indonesia seiring dengan usaha pemenuhan hak bagi mayoritas muslim di Indonesia yang menginginkan adanya fasilitas keuangan yang sesuai dengan kepercayaannya.

Spin Off dipandang dari sisi ketaatan syariah merupakan upaya menjadikan Bank Syariah yang lebih murni dan terpisah dari Bank Konvensional agar lebih mematuhi prinsip kehati-hatian dalam bertransaksi secara syariah. Sebab, secara eksplisit dari falsafah dasarnya jelas menunjukkan adanya perbedaan antara Bank Konvensional dengan Bank Syariah. Mekanisme Bank Syariah menggunakan bagi hasil (profit and loss sharing/PLS), sedangkan Bank Konvensional menggunakan sistem bunga (interest based system/IBS). Prinsip inilah yang secara mendasar sangat membedakan kedua jenis perbankan tersebut sehingga perlu dipisahkan (Tohirin, 2013).

Berdasarkan data statistik perbankan syariah yang di publikasikan 
oleh Otoritas Jasa Keuangan Periode Juli 2020 diketahui nama dan jumlah Bank Umum Syariah (BUS) serta nama dan jumlah Unit Usaha Syariah (UUS) yang belum melakukan pemisahan (spin off) adalah Sebagai Berikut:

Tabel 1. Nama Bank Umum Syariah dan Unit Usaha Syariah

\begin{tabular}{|c|c|}
\hline No $\quad$ Bank Umum Syariah & No Unit Usaha Syariah \\
\hline $1 \quad$ PT. Bank Aceh Syariah & 1 PT Bank Danamon Indonesia, Tbk \\
\hline PT. BPD Nusa Tenggara Barat Syariah & 2 PT Bank Permata, Tbk \\
\hline PT. Bank Muamalat Indonesia & 3 PT. Bank Maybank Indonesia, Tbk \\
\hline PT. Bank Victoria Syariah & 4 PT Bank CIMB Niaga, Tbk \\
\hline PT. Bank BRI Syariah & 5 PT Bank OCBC NISP, Tbk \\
\hline PT. Bank Jabar Banten Syariah & $6 \quad$ PT Bank Sinarmas \\
\hline $7 \quad$ PT. Bank BNI Syariah & 7 PT Bank Tabungan Negara (Persero), Tbk. \\
\hline PT. Bank Syariah Mandiri & 8 PT BPD DKI \\
\hline 9 PT. Bank Mega Syariah & PT BPD Daerah Istimewa Yogyakarta \\
\hline 10 PT. Bank Panin Dubai Syariah & 10 PT BPD Jawa Tengah \\
\hline 11 PT. Bank Syariah Bukopin & 11 PT BPD Jawa Timur, Tbk \\
\hline PT. BCA Syariah & 12 PT BPD Sumatera Utara \\
\hline $\begin{array}{l}13 \text { PT. Bank Tabungan Pensiunan } \\
\text { Nasional Syariah }\end{array}$ & 13 PT BPD Jambi \\
\hline \multirow[t]{7}{*}{14 PT. Maybank Syariah Indonesia } & 14 PT BPD Sumatera Barat \\
\hline & 15 PT BPD Riau dan Kepulauan Riau \\
\hline & 16 PT BPD Sumatera Selatan dan Bangka Belitung \\
\hline & 17 PT BPD Kalimantan Selatan \\
\hline & 18 PT BPD Kalimantan Barat \\
\hline & 19 PD BPD Kalimantan Timur \\
\hline & 20 PT BPD Sulawesi Selatan dan Sulawesi Barat \\
\hline
\end{tabular}

\section{Sumber : Otoritas Jasa Keuangan (2020)}

Berdasarkan data pada Tabel 1.1. diketahui bahwa jumlah Bank Umum Syariah adalah sebanyak 14 Bank, dengan jumlah kantor sebanyak 1.940, jumlah Unit Usaha Syariah (Bank Konvensional yang memiliki Unit Usaha Syariah) adalah sebanyak 20 UUS yang belum melakukan pemisahan (spin off), dengan jumlah kantor sebanyak 389. Sedangkan, Bank Pembiayaan Syariah berjumlah 162. Artinya, terdapat 20 Unit Usaha Syariah milik Bank Umum Konvensional harus segera mempersiapkan diri melakukan pemisahan (spin off) menjadi BUS paling lambat pada tahun 2023 atau 3 tahun lagi.

Kewajiban spin off pada tahun 2023 atau 3 tahun lagi, semakin sulit terwujud karena adanya tekanan ekonomi dari Pandemi Covid-19. Tekanan ekonomi yang terjadi mengakibatkan penurunan fungsi intermediasi perbankan. Yaitu Pembiayaan dan Dana Pihak Ketiga (DPK) semua bank menunjukkan adanya gejolak (Ningsih \& Mahfudz, 2020)

Oleh karena itu perlu ada upaya dari Bank Umum Konvensional yang memiliki Unit Usaha Syariah untuk mencari solusi agar amanah Undangundang No. 21 Tahun 2008 dapat terlaksana. Demi mendukung kebijakan pemerintah untuk meningkatkan pangsa pasar perbankan syariah.

Unit Usaha PT. BPD Riau dan Kepulauan Riau Syariah atau yang umum dikenal PT. Bank Riau Kepri Syariah merupakan Unit Usaha Syariah yang dimiliki oleh Bank Umum Konvensional yakni PT. Bank Riau Kepri yang diawali dengan restrukturisasi organisasi di Bank 
Riau Kepri untuk membentuk Unit Usaha Syariah sesuai dengan Surat Keputusan Direksi No. 44/KEPDIR/2002 pada Tanggal 01 Oktober 2002. Yang Di resmikan oleh Gubernur Riau Pada tanggal 22 Juli 2004.

Beroperasinya Bank Riau Kepri Syariah di dorong oleh beberapa faktor diantaranya; pertama, adanya fakta bunga bank haram dari Majelis Ulama Indonesia pada akhir tahun 2003. Kedua, Adanya Undang-undang No. 10 tahun 1998 tentang Perubahan Undang-undang No. 7 tahun 1992 tentang Perbankan. Berdasarkan UU tersebut memberikan peluang bagi Bank umum Konvensional untuk ikut serta menangani transaksi Perbankan Syariah. Ketiga, adanya potensi pasar yang cukup besar di Riau dan Kepulauan Riau, mengingat mayoritas penduduknya beragama Islam. Hal ini bisa dilihat dari market share di Riau adalah Sebesar 6,80\% dan Kepulauan Riau sebesar 6,03\% Dengan total market share Riau dan Kepulauan Riau sebesar 12,83\%. Total pertumbuhan aset sebesar 52,42\%, dan Total Pertumbuhan DPK Sebesar $74.64 \%$. di mana angka ini merupakan angka Tertinggi kedua di wilayah Sumatera bagian Utara setelah Nangroe Aceh Darussalam.

Disisi lain, kinerja Bank Riau Kepri Syariah menunjukkan peningkatan dari tahun ke tahun, pada tahun 2017 Bank Riau Kepri Syariah berhasil meraih penghargaan Karim Award 2017 yakni penghargaan "The Most Expanding Funding UUS Asset RP. 1,5 T. Penghargaan tersebut dikategorikan menjadi empat yaitu Best Islamic Banking (BUKU I), Best Islamic Banking (BUKU II dan Buku III), Best Islamic Banking (UUS Aset $=1,5 \mathrm{~T}$ ) Dan Best Islamic Banking (UUS $=1,5 \mathrm{~T}$ ). Penghargaan tersebut dinilai berdasarkan latest audited financial report yaitu periode 31 Desember 2015 dan 31 Desember 2016, dengan penilaian faktor pertumbuhan vertikal (pertumbuhan dana pihak ketiga UUS Bank Riau Kepri) dan pertumbuhan horizontal (tambahan market share dana pihak ketiga UUS Bank Riau Kepri).

Pada tahun 2019 Bank Riau Kepri Unit Layanan Syariah berhasil meraih penghargaan kinerja keuangan terbaik (excellent) untuk kinerja keuangan pada tahun 2018. kategori Bank Pembangunan Daerah (BPD). Hal ini mengindikasikan Unit Usaha Syariah PT. BPD Riau dan Kepulauan Riau memiliki peluang yang cukup besar untuk melakukan pemisahan (spin off) jika dilihat dari pangsa pasarnya. baik dengan cara pemisahan murni (mendirikan Bank Umum Syariah Baru) atau mengalihkan hak dan kewajiban Unit Usaha Syariah kepada Bank Umum Syariah yang telah ada. Atau bahkan melakukan konversi/perubahan kegitan usaha Bank Riau Kepri selaku Bank Induk menjadi Bank Riau Kepri Syariah. Sebab, cepat atau lambat Unit Usaha Syariah milik Bank Umum Konvensional harus segera melakukan pemisahan sesuai dengan amanat Undang-undang No. 21 Tahun 2008 Tentang Perbankan Pasal 68. Hal ini dilakukan agar tidak ada pencabutan izin Unit Usaha Syariah Bank Umum Konvensional sesuai peraturan dalam UU No. 21 Tahun 2008.

\section{TINJAUAN PUSTAKA}

\section{Bank Syariah}

Menurut Dahlan (2004) bank syariah merupakan bank yang menjalankan usaha perbankan dengan berdasar ataupun memperhatikan prinsipprinsip syariah yang tertuang di dalam AlQur'an dan Hadist.

Menurut Sudarsono (2003) bank syariah merupakan salah satu lembaga keuangan negara yang memberikan kredit dan jasa-jasa perbankan lainnya di dalam lalu lintas pembayaran dan peredaran uang yang beroperasi dengan berdasarkan prinsip-prinsip agama Islam atau pun prinsip syariah. 
Menurut A. Perwataatmadja, dkk (1992) pengertian bank syariah adalah bank yang beroperasi dengan mengikuti prinsip-prinsip syariah ataupun Islami yang tata cara pelaksanaannya didasarkan pada ketentuan Al-Qur'an dan Hadist.

Menurut UU No. 21 Tahun 2008, perbankan syariah yaitu segala sesuatu yang berkaitan bank syariah dan unit usaha syariah yang mencakup kelembagaan, kegiatan usaha, hingga proses pelaksanaan kegiatan usahanya. Bank syariah merupakan bank yang menjalankan aktivitas usahanya dengan menggunakan landasan prinsip-prinsip syariah yang terdiri dari BUS (Bank Umum Syariah), BPRS (Bank Perkreditan Rakyat Syariah), dan UUS (unit Usaha Syariah).

Bank Umum Syariah Bank Umum Syariah adalah Bank Syariah yang dalam kegiatannya memberikan jasa dalam lalu lintas pembayaran.

Unit Usaha Syariah yang selanjutnya disebut UUS, adalah unit kerja dari kantor pusat Bank Umum Konvensional yang berfungsi sebagai kantor induk dari kantor atau unit yang melaksanakan kegiatan usaha berdasarkan prinsip syariah, atau unit kerja di kantor cabang dari suatu Bank yang berkedudukan di luar negeri yang melaksanakan kegiatan usaha secara konvensional yang berfungsi sebagai kantor induk dari kantor cabang pembantu syariah dan/atau unit syariah.

Bank Pembiayaan Syariah adalah Bank Syariah yang dalam kegiatannya tidak memberikan jasa dalam lalu lintas pembayaran.

\section{METODE PENELITIAN}

Penelitian ini bersifat gagasan deskriptif yang dilakukan dengan kegiatan investigasi teoritis (literature review) untuk membangun kerangka konseptual (conceptual framework) yang digunakan sebagai rujukan konseptual untuk membentuk argumentasi strategi apa saja yang harus di lakukan agar Unit Usaha Syariah PT. BPD Riau segera melakukan spin off makimal pada tahun 2023 atau bahkan melakukan konversi menjadi Bank Riau Kepri Syariah.

\section{HASIL DAN PEMBAHASAN}

\section{Pemisahan (Spin Off)}

Pemisahan (spin off) merupakan pemisahan usaha dari satu Bank menjadi dua badan usaha atau lebih, sesuai dengan ketentuan peraturan perundang-undangan No. 21 Tahun 2008 Tentang Perbankan Syariah Pasal I ayat 32.

Selain itu pengertian pemisahan (spin off) adalah perbuatan hukum yang dilakukan perseroan untuk memisahkan usaha yang mengakibatkan seluruh aktiva dan passiva Perseroan beralih karena hukum kepada satu Perseroan atau lebih (UU No. 40 Tahun 2007 Tentang Perseroan Terbatas Pasal 1 ayat 12) yang mana bentuk badan hukum perbankan syariah merupakan perseroan terbatas. Sehingga dapat di ketahui bahwa pemisahan (spin off) Unit Usaha Syariah Bank Umum Konvensional merupakan proses pemisahan Unit Usaha Syariah dari Bank Umum Konvensional selaku Bank Induk menjadi Bank Umum Syariah yang berbadan hukum sendiri yang mandiri dan independen. Artinya, Unit Usaha Syariah yang sudah memisahkan diri tidak bisa lagi kembali ke Bank Umum Konvensional setelah memutuskan untuk melakukan pemisahan (spin off) dan menjadi Bank Umum Syariah.

Alasan Pemisahan (spin off) yang ditempuh sistem perbankan di Indonesia dapat ditinjau dari 2 aspek yaitu :

1. Secara ekonomis pemisahan ini memperluas kegiatan usaha Unit Usaha Syariah (UUS) menjadi setara dengan Bank Umum Syariah yakni menjamin penertiban surat berharga, 
penitipan untuk kepentingan orang lain, menjadi wali amanat, penyertaan modal, pengurusan dana pensiun, dan menertibkan, menawarkan serta memperdagangkan surat berharga jangka panjang.

2. Secara ideologis pemisahan ini mendukung pemisahan sistem syariah dari sistem konvensional. Dengan pemisahan Unit Usaha Syariah menjadi Bank Umum Syariah maka lembaga ini secara langsung terpisah dari Bank Umum Konvensional dan menumbuhkan kepercayaan masyarakat (umat muslim) akan kemurnian lembaga keuangan syariah.

Pemisahan Unit Usaha Syariah dari Bank Umum Konvensional dapat dilakukan dengan cara berikut:

1. Mendirikan Bank Umum Syariah baru, yakni Unit Usaha Syariah Bank Umum Konvensional memisahkan diri dari bank induk untuk menjadi Bank Umum Syariah. Yang mana pendirian Bank Umum Syariah hasil pemisahan dapat dilakukan oleh 1 atau lebih Bank Umum Konvensional yang memiliki Unit Usaha Syariah.

2. Mengalihkan hak dan kewajiban Unit Usaha Syariah kepada Bank Umum Syariah yang telah ada. Pemisahan Unit Usaha Syariah dengan cara pengalihan kepada Bank Umum Syariah hanya dapat dilakukan kepada Bank Umum Syariah yang mempunyai hubungan kepemilikan dengan Bank Umum Konvensional yang memiliki Unit Usaha Syariah.

\section{Strategi Unit Usaha Syariah Melakukan Spin Off}

Untuk melaksanakan amanah Undang-undang No. 21 Tahun 2008 maka diperlukan langkah-langkah strategis agar Unit Usaha Syariah dapat melaksanakan kewajiban pemisahan (spin off) pada tahun 2023, yakni dengan melihat berbagai aspek sebagai berikut:

\section{Tahapan Proses Spin Off atau Konversi}

Pada aspek ini, tahapan proses untuk segera melaksanakan kewajiban spin off diawali dengan Persiapan (pra) spin off. Unit Usaha Syariah PT. BPD Riau dan Kepulauan Riau telah melakukan berbagai upaya dan persiapan untuk mewujudkan kewajiban spin off menjelang Tahun 2023. Salah satunya melalui Usulan spin off yang diajukan pada saat Rapat Umum Pemegang Saham Luar Biasa (RUPS-LB). Hal ini diperkuat dengan pernyataan DR. Irvandi Gustari Direktur Utama Bank Riau Kepri PT. BPD Riau dan Kepulauan Riau telah melakukan pengkajian proses spin off pada tahun 2017 yang berakhir pada Desember 2017 dengan melakukan sejumlah tahapan persiapan. Pengkajian proses spin off adalah salah satu langkah persiapan bank menuju spin off antara layanan konvensional dan layanan berbasis syariah. Pengkajian yang dilakukan yakni dari segi bisnis, operasional, hukum dan kompetensi sumber daya insani (SDI) serta produk.Setelah dilaksanakan proses pengkajian spin off, maka PT. BPD Riau dan Kepulauan Riau melakukan persiapan penuh untuk pemisahan spin off yakni dari permodalan dan regulasi daerah.

Namun, di tengah-tengah persiapan menuju spin off Unit Usaha Syariah PT. Bank Riau Kepri pada akhirnya memilih melakukan konversi/perubahan kegiatan usaha menjadi Bank Riau Kepri Syariah. Hal ini sesuai dengan amanat Gubernur Riau selaku pemegang saham terbanyak.

Untuk mewujudkan konversi dari Bank Umum Konvensional menjadi Bank Umum Syariah PT. BPD Riau telah melakukan berbagai persiapan salah satunya adalah melakukan berbagai kajian akademik dan langkah-langkah strategis 
dengan mengacu pada peraturan Otoritas Jasa Keuangan, No. 64/POJK.03/2016 Pasal 6 yakni Bank Konvensional yang akan melakukan perubahan kegiatan usaha menjadi bank syariah harus melakukan Hal-hal Sebagai Berikut:

1. Menyesuaikan anggaran dasar yang mengacu pada Undang-Undang yang mengatur Perbankan Syariah.

2. Memenuhi persyaratan permodalan sesuai dengan ketentuan permodalan Bank Umum Syariah.

3. Menyesuaikan persyaratan Direksi dan Dewan Komisaris yang memenuhi ketentuan dalam mengatur Bank Umum Syariah.

4. Membentuk DPS sebagai mana di atur dalam ketentuan Bank Umum Syariah.

5. Menyajikan laporan keuangan qwal sebagai Bank Syariah.

Persiapan lainnya yang dilakukan oleh PT. BPD Riau dan Kepulauan Riau menuju syariah adalah dengan mengadakan seminar executive overview of Islamic Bank for legislative. Hal ini dilakukan untuk mempercepat adanya Peraturan Daerah terkait dengan konversi Bank Riau Kepri Syariah.

\section{Aspek Bisnis}

Target kegiatan usaha jangka panjang yang ingin di capai oleh PT. BPD Riau dan Kepulauan Riau adalah menjadi perbankan yang mampu berkembang dan terkemuka di daerah, memiliki manajemen yang profesional dan mendorong pertumbuhan perekonomian daerah sehingga dapat memberdayakan perekonomian rakyat.

Sedangkan target kegiatan usaha jangka panjang yang ingin di capai oleh Unit Usaha Syariah PT. BPD Riau dan Kepulauan Riau adalah menjadi mitra syariah jasa layanan perbankan yang terkemuka di daerah, sehat dan kompetitif sesuai dengan ketentuan syariah sehingga secara teguh, utuh dan tumbuh memenuhi prinsip kehati-hatian, mampu mendukung sektor rill dan konsisten menjalankan prinsip syariah secara optimal.

Upaya yang di tempuh untuk pencapaian target tersebut adalah melalui proses spin off yang sudah mulai disetujui sejak tanggal 09 februari 2018, Namun di tengah-tengah persiapan menuju pemisahan (spin off) pada akhirnya PT. BPD Riau dan Kepulauan Riaumemutuskan untuk melakukan perubahan kegiatan usaha, yakni dari Bank Konvensional menjadi Bank Syariah atau lebih di kenal dengan Konversi PT. Bank Riau Kepri Syariah. Sesuai dengan amanah dari para pemegang saham. Hal ini dilakukan dalam rangka memperluas usaha PT. BPD Riau dan Kepulauan Riau, karena mayoritas penduduk di Riau dan Kepulauan Riau adalah beragama Islam. Selain itu juga di dorong oleh adanya fakta bunga bank haram dari Majelis Ulama Indonesia pada akhir tahun 2003.

PT. BPD Riau dan Kepulauan Riau selaku pemegang saham utama dari Bank Riau Kepri Syariah selama ini telah berupaya untuk menyiapkan Sumber Daya Manusia melalui pelatihan agar siap untuk ditempatkan di Bank Riau Kepri Syariah, Setelah itu PT. BPD Riau dan Kepulauan Riau juga melakukan persiapan Susunan Organisasi dan Tata Kerja (SOTK), Standar Operasional Prosedur (SOP), kantor pusat, teknologi serta menyiapkan direktur, pengurus dan komisaris untuk Bank Riau Kepri Syariah.

Langkah spin off ataupun konversi yang akan dilakukan oleh PT. BPD Riau dan Kepulauan Riau merupakan salah satu cara dalam pengembangan usaha atau bisnis. Sebab, peluang pertumbuhan potensial, dengan konsep syariah dirasakan sangat tinggi di Riau. Melalui pemisahan ataupun konversi tersebut, nasabah akan semakin yakin untuk kesyariahannya. Sehingga secara langsung 
akan meningkatkan Dana Pihak Ketiga (DPK).

\section{Aspek Keuangan}

Berdasarkan Laporan Keuangan PT. BPD Riau dan Kepulauan Riau 5 tahun terakhir dapat di ketahui perkembangan asset mengalami peningkatan dari tahun ke tahun di mana aset 2015 sebesar Rp. 19.737.540 meningkat sebesar 6,99\% menjadi Rp. 21.220.940 pada tahun 2016, selanjutnya pada tahun 2017 mengalami peningkatan kembali menjadi Rp 25.492 .549 (meningkat sebesar 16,75\%), tahun 2018 asset Bank Riau Kepri tumbuh menjadi Rp. 27.414.273 (meningkat sebesar 7,01\%). Akan tetapi asset PT. BPD Riau dan Kepulauan Riau mengalami penurunan sebesar 7,16\% pada tahun 2019 menjadi Rp. 25.452.114.

Meskipun mengalami penurunan namun, pertumbuhan asset pada tahun 2019 tergolong cukup tinggi mengingat kondisi ekonomi global yang terus mengalami penurunan.

Jika di lihat dari sisi Dana Pihak Ketiga, diketahui bahwa Pertumbuhan Dana Pihak Ketiga (DPK) Bank Riau Kepri tahun 2019 tumbuh sebesar 17,52\% atau tumbuh Rp. 2.972.797 juta dari Rp. 16.964.254 juta tahun 2018 menjadi Rp. 19.937.051 juta tahun 2019 .

Begitu juga jika dilihat dari aktiva produktif ditargetkan tumbuh sebesar Rp. 24.303.461 juta dan terealisasi sebesar Rp. 22.231.939 juta atau pencapaian sebesar 91,48\% dari target. Laba bersih tahun berjalan bank pada tahun 2019 sebesar Rp. 314.332 juta, dari target sebesar Rp. 322.500 juta atau pencapaian $97,47 \%$.

Selanjutnya, Aspek keuangan Unit Usaha Syariah PT. BPD Riau dan Kepulauan Riau di tinjau dari sisi aset mengalami peningkatan pertumbuhan aset sebesar $11,47 \%$ pada semester I tahun 2020 dibandingkan dengan posisi akhir tahun lalu. Sehingga Aset Unit Usaha Syariah PT. BPD Riau dan Kepulauan Riau menjadi Rp. 3,35 Triliun. Walaupun kinerja sangat baik di tunjukkan oleh Unit Usaha Syariah PT. BPD Riau dan Kepulauan Riau. Jika di lihat dari laporan keuangan yang ada saat ini, Unit Usaha Syariah PT. BPD Riau dan Kepulauan Riau tetap harus mendapatkan tambahan modal untuk menambah asetnya (jika keputusan yang di ambil adalah melakukan spin off tambahan modal tersebut bisa dari bank induk dan bisa juga dari stakeholder yakni dari daerah-daerah yang ada di Provinsi Riau.

Berdasarkan Akta Berita Acara Rapat Umum Pemegang Saham Luar Biasa Perseroan Terbatas "Bank Pembangunan Daerah Riau Kepri" yang dibuat oleh Notaris Pupung Mulyantini, SH. MH Akta tanggal 09 Februari 2018 Nomor 11, menyetujui atas alternatif modal dalam rangka pelaksanaan spin off Unit Usaha Syariah menjadi Bank Umum Syariah adalah Holding Company dan besaran penyertaan modal yang dapat disertakan Bank Riau Kepri di Bank Umum Syariah Riau Kepri adalah sebesar minimal menurut ketentuan yang berlaku.

Akan tetapi Berdasarkan Akta Berita Acara Rapat Umum Pemegang Saham Luar Biasa Perseroan Terbatas "Bank Pembangunan Daerah Riau Kepri" Disingkat "PT Bank Riau Kepri" Akta Notaris Pupung Mulyantini, SH.MH tanggal 22 April 2019 Nomor 13. Rapat Umum Pemegang Saham (RUPS) menyetujui konversi/perubahan kegiatan usaha Bank Riau Kepri menjadi Bank Umum Syariah.

\section{Aspek Organisasi Dan Sumber Daya Insani (SDI)}

Pengembangan Organisasi merupakan suatu usaha perubahan yang mencoba untuk meningkatkan efektivitas dari sebuah organisasi. PT. BPD Riau dan Kepulauan Riau melakukan berbagai 
upaya dalam rangka pengembangan organisasi, salah satunya adalah melalui morning briefing dengan pegawai untuk menyampaikan kendala-kendala yang dihadapi untuk mencapai rencana bisnis yang telah di susun.

Selain itu, untuk pengembangan organisasi PT. BPD Riau dan Kepulauan Riau selalu mengelola Sumber Daya Manusia dengan berbagai program strategis antara lain pemetaan ulang terhadap komposisi pegawai (bisnis dan non bisnis, kantor pusat dan kantor cabang, program pengembangan karir berbasiskan kinerja dan kompetisi termasuk penerapan konsep e-recruitment (rekrutmen online), penerapan konsep lelang dan talent management pada program pengembangan karir.

PT. BPD Riau dan Kepulauan Riau juga fokus dalam peningkatan kompetensi pada seluruh pegawai melalui program pelatihan dan pengembangan yang terpadu pada Learning Center Program, termasuk program pendidikan pegawai di perguruan tinggi terkemuka di luar negeri, internalisasi program budaya kerja produktif secara berkesinambungan, penerapan KPI yang transparan dan terukur pada semua lini pegawai termasuk Direksi, review dan evaluasi serta implementasi pola remunerasi yang selaras dengan beban dan tanggung kerja dan dibandingkan dengan peer group, penerapan Human Resources Information System (HRIS) serta pemenuhan jumlah pegawai pada business unit : funding officer dan relationship officer dalam percepatan pertumbuhan bisnis.

PT. BPD Riau dan Kepulauan Riau juga selalu melakukan penilaian terhadap komite pendukung yang telah berperan efektif dan mampu menjalankan tugasnya dengan baik dalam membantu pelaksanaan tugas Direksi. Penilaian tersebut dilakukan oleh direksi kepada
Komite Manajemen Risiko, Komite Kebijakan Perkreditan, Asset and Liability Committee (ALCO), Komite Pengarah Teknologi Informasi (TI), Komite SDM, Komite Anti Fraud, dan Komite Pembiayaan.

Selain Upaya yang dilakukan oleh PT. BPD Riau dan Kepulauan Riau selaku Bank Induk, Unit Usaha Syariah PT. BPD Riau dan Kepulauan Riau juga berupaya untuk pengembangan organisasi adalah melalui pelatihan untuk pegawai Bank Riau Kepri Syariah wilayah Riau Daratan yang diselenggarakan oleh ESQ Leadershio di Ballroom Dang Merdu Lt.4 Gedung Menara Dank Merdu Bank Riau Kepri. Selain itu, Pelatihan pegawai juga dilaksanakan pada Unit Usaha Syariah PT. BPD Riau dan Kepulauan Riau yang beroperasi di Provinsi Kepulauan Riau mencakup Cabang Syariah Tanjung Pinang, Tanjung Balai Karimun dan Batam, serta pegawai Unit Layanan Syariah (ULS) Pada setiap kantor Bank Riau Kepri di Provinsi Kepulauan Riau.

Pelatihan untuk pegawai Bank Riau Kepri Syariah bertujuan untuk mempersiapkan Sumber Daya Manusia dalam rangka peningkatan kinerja, motivasi, dan etos kerja serta membangun kompetensi dan karakter bagi unit kerja syariah baik divisi syariah maupun di Cabang dan Cabang Pembantu Syariah menuju proses pelaksanaan spin off atau konversi.

Untuk mempercepat proses konversi maka PT. BPD Riau dan Kepulauan Riau melakukan langkahlangkah pengembangan organisasi dan sumber daya insani yakni dengan:

1. Mendorong pengembangan kompetensi strategis.

2. Membangun sistem pengelolaan SDM Yang terintegrasi, dan

3. Membangun budaya organisasi yang berorientasi pada kinerja. 


\section{Aspek Teknologi dan Informasi}

Aspek Teknologi dan Informasi adalah salah satu langkah strategis untuk melihat kesiapan sistem teknologi, sistem mobile banking, Ketersediaan Informasi produk baru atau yang berkaitan dengan kegiatan usahayang dimiliki oleh Unit Usaha Syariah PT. BPD Riau dan Kepulauan Riau untuk melakukan pemisahan (spin off) atau konversi menjadi PT. BPD Riau dan Kepulauan Riau Syariah.

Unit Usaha Syariah PT. BPD Riau dan Kepulauan Riau belum memiliki sistem teknologi perbankan sendiri, karena masih menggunakan teknologi perbankan yang sama dengan bank induk. Saat ini, PT. BPD Riau dan Kepulauan Riau sudah memiliki layanan ATM Setor Tunai, sehingga akan memudahkan Nasabah untuk melakukan transaksi keuangannya dengan menggunakan Kartu ATM/Debit IB. Selain itu Bank Riau Kepri juga telah memiliki EDC yang merupakan mesin gesek kartu yang dapat digunakan untuk menerima transaksi pembayaran (purchase) dengan semua kartu ATM dan kartu debit Bank Riau Kepri yang diletakkan di merchant terkenal di Provinsi Riau dan Provinsi Kepulauan Riau.

PT. BPD Riau dan Kepulauan Riau juga memiliki Layanan mobile Banking pada smartphone dengan tampilan menu yang menarik dan mudah digunakan. Dengan Mobile Banking Bank Riau Kepri, nasabah dapat melakukan transaksi finansial (transfer, pembayaran, pembelian, dll), transaksi non finansial (cek saldo, cek histori transaksi, dll), informasi lokasi Cabang/ATM, informasi kurs dan fitur-fitur lainnya. Selain layanan Mobile Banking juga tersedia layanan sms and phone, layanan jasa pengiriman uang dalam valuta asing (Remittance), serta transaksi ekspor impor (Trade Finance and Services).
Berdasarkan uraian di atas, dapat diketahui bahwa sejauh ini sistem teknologi Unit Usaha Syariah belum memadai untuk dilakukan pemisahan (spin off), namun berdasarkan pernyataan dari Direktur Utama PT. BPD Riau dan Kepulauan Riau bahwa modal untuk melakukan spin off akan diberikan oleh Bank Induk yakni PT. BPD Riau dan Kepulauan Riau dan menjadi pemegang saham pengendali. Sehingga masih memungkinkan untuk menggunakan teknologi perbankan yang sama.

Begitu juga dengan sistem mobile banking Unit Usaha Syariah PT. BPD Riau dan Kepulauan Riau masih menggunakan sistem mobile banking dari bank induk, sehingga untuk proses pemisahan (spin off) diperlukan sistem mobile banking milik sendiri selaku Bank Umum Syariah. Akan tetapi jika Bank Induk melakukan perubahan kegiatan usaha/konversi maka teknologi yang di miliki sudah sangat memadai.

Untuk ketersediaan informasi produk baru dan informasi lainnya yang berkaitan dengan kegiatan usaha bisa diakses di https://www.bankriaukepri.co.id/riau_syar iah, melalui Ketersediaan Informasi yang selalu terbarukan, maka pemerintah, masyarakat maupun investor akan mudah untuk mengetahui informasi mengenai produk-produk yang ditawarkan serta keuntungan yang akan di dapatkan jika melakukan transaksi atas suatu produk. Hal ini tentunya akan mendorong untuk peningkatan Dana Pihak Ketiga, sehingga secara langsung akan mendorong percepatan untuk pemisahan (spin off).

Jika Unit Usaha Syariah sudah menjadi Bank Umum Syariah, maka harus memiliki pusat informasi sendiri sebagai sarana dan prasarana penunjang penyampaian informasi untuk stakeholder dan pihak-pihak yang memiliki 
kepentingan. Selain itu juga berfungsi untuk keterbukaan informasi publik.

Adapun ketersediaan informasi tersebut antara lainberisikan informasi: Profil Perusahaan, Visi \& Misi, Program Transformasi, Struktur Organisasi, Struktur Kepemilikan, Profil Organisasi, Info Lainnya, Corporate Secretary dan Anggaran Dasar, Ikhtisar Keuangan, Laporan Keuangan, Informasi Kuantitatif Eksposur Risiko, Informasi RUPS, Laporan GCG, Kode Etik, Pedoman Kerja Direksi, Pedoman Kerja Komite, Kebijakan Manajemen Risiko, CSR dan BPP pelaksanaan Tata Kelola, Produk \& Jasa, Konsumer, Mikro, Komersial, Syariah, jenis-jenis pembiayaan, akad yang digunakan. Jaringan Kantor dan ATM Berita aktivitas Bank Riau Kepri Mobile Banking, Bagaimana memperoleh Bank Riau Kepri Mbanking, dan informasi lainnya yang berhubungan dengan kegiatan usaha atau operasional Bank.

Maka, dapat di ambil kesimpulan bahwa ketersedian informasi adalah hal yang sangat penting untuk perkembangan kinerja perbankan selanjutnya, oleh karena itu agar spin off dapat dilaksanakan secepatnya maka Unit Usaha Syariah harus memperbaiki sistem informasi yang saat ini di milikinya. Namun jika bank induk akan melakukan konversi, maka sistem informasi yang di miliki sudah sangat memadai.

\section{Aspek Legal dan Perizinan}

Unit Usaha Syariah PT. BPD Riau dan Kepulauan Riau sudah mulai mempersiapkan segala proses pengajuan izin dan penyertaan modal untuk pelaksanaan spin off setelah usulan spin off disetujui oleh para pemegang saham pada Rapat Umum Pemenang Saham Luar Biasa (RUPS-LB) dan saat ini telah mengajukan izin prinsip dan izin usaha sehingga proses pemisahan (spin off) segera dapat terealisasi.
Proses pengajuan izin prinsip pendirian BUS dan pemisahan UUS dilakukan dengan mempersiapkan permohonan untuk persetujuan prinsip pendirian Bank Umum Syariah dalam rangka Pemisahan Unit Usaha Syariah dan untuk mendapatkan izin tersebut, PT. BPD Riau dan Kepulauan Riau akan mempercepat proses penyertaan modal untuk Unit Usaha Syariah PT. BPD Riau dan Kepulauan Riau.

Setelah pengajuan izin prinsip selesai dilaksanakan maka Proses pengajuan izin usaha serta proses transfer asset/spin off UUS ke BUS yang akan dilaksanakan. Saat ini Bank Riau Kepri Sedang menyiapkan pengurusan izin spin off Unit Usaha Syariah ke Otoritas Jasa Keuangan (OJK).

Akan tetapi keputusan pemisahan (spin off) UUS PT. BPD Riau dan Kepulauan Riau berubah menjadi konversi atau perubahan kegiatan usaha Bank Induk sesuai dengan amanah Rapat Umum Pemegang Saham (RUPS) pada tanggal 22 April 2019 Nomor 13.

Saat ini PT. BPD Riau dan Kepulauan Riau sedang melakukan berbagai upaya untuk mendapatkan legalitas diantaranya Peraturan Daerah (Perda) tentang konversi Bank Riau Kepri Syariah, untuk pencapaian ini, maka PT. BPD Riau dan Kepulauan Riau sudah melakukan Seminar Executive Overview of Islamic Bank For Legislative. Hal ini dilakukan agar anggota dewan dapat mengenal produk serta mekanisme dari PT. Bank Riau Kepsi Syariah nantinya, sehingga menjadi lebih mudah untuk menetapkan legalitasnya dari sisi peraturan daerah.

Selain itu PT. BPD Riau dan Kepulauan Riau juga sedang menyiapkan Akta Pendirian beserta kelengkapan perizinan untuk mempercepat proses konversi menjadi PT. BPD Riau dan Kepulauan Riau Syariah. 


\section{KESIMPULAN}

Langkah-langkah strategis yang dilakukan oleh Unit Usaha Syariah PT. BPD Riau dan Kepulauan Riau dalam menunaikan amanat UU No.21 Tahun 2008 Tentang Perbankan Syariah menunjukkan bahwa Unit Usaha Syariah PT. BPD Riau dan Kepulauan Riau sudah melakukan proses pengurusan pemisahan $(\operatorname{spin}$ off), hal ini ditandai denganpersetujuan untuk spin off pada tanggal 09 Februari 2018 Nomor 11. Namun, di tinjau dari tahapan spin off, aspek bisnis, aspek keuangan, aspek sumber daya insani,aspek tekhnologi dan informasi, serta aspek perizinan maka untuk melakukan pemisahan (spin off) masih menemukan berbagai kendala diantaranya aspek keuangan serta aspek tekhnologi dan informasi yang mengganggu proses perizinan dan legalitas, sehingga untuk melakukan pemisahan (spin off), membutuhkan persiapan yang sangat banyak diantaranya penyertaan modal dan penyediaan tekhnologi dan informasi milik Unit Usaha Syariah Sendiri untuk mendukung spin off tersebut. Oleh karena itu berdasarkan amanah Rapat Umum Pemegang Saham (RUPS) pada tanggal 22 April 2019 Nomor 13 maka PT. BPD Riau dan Kepulauan Riau memutuskan untuk melakukan konversi/perubahan kegiatan usaha menjadi Bank Umum Syariah. Sehingga kendala permodalan serta kepemilikan teknologi dan informasi yang menghambat proses spin off bisa teratasi jika Bank Induk memilih untuk melakukan konversi menjadi Bank Umum Syariah.

\section{DAFTAR PUSTAKA}

A. Perwataatmadja, Karnaen dan Syafi'i Antonio. 1992. Apa dan Bagaimana Bank Syariah. Dana Bhakti Wakaf. Yogyakarta.

Dahlan, Siamat. 2004. Manajemen Lembaga Keuangan, Edisi Keempat.
Lembaga Penerbit Fakultas Universitas Indonesia. Jakarta.

Indra, Suhendra \& Edwin, Ronaldo. 2017. Pengaruh Intermediasi Perbankan Terhadap Pertumbuhan Ekonomi Indonesia. Tirtayasa Ekonomika, 12(1), 169-195.

Ningsih, Mardhiyatur Rosita \& Mahfudz, Muhammad Syarqim. 2020. Dampak Pandemi Covid-19

Terhadap Manajemen Industri Perbankan Syariah: Analisis Komparatif, POINT, 2(1), 1-10.

Rongiyati, Sulasi. 2015. Pengembangan Perbankan Syariah Melalui Pelaksanaan Kewajiban Pemisahan Unit Usaha Syariah. NEGARA HUKUM, 6(1), 65-78.

Sudarsono, Heri. 2003. Bank dan Lembaga Keuangan Syari'ah Deskripsi dan Ilustrasi. Ekonisia. Yogyakarta.

Tohirin, Achmad. 2003. Implementasi Perbankan Islam : Pengaruh Sosio Ekonomis dan peranannya dalam pembangunan. Jurnal Ekonomi Pembangunan, 8(1), 73-88. 